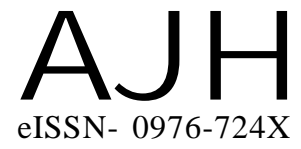

Received : 08.02.2017

Revised : 19.04.2017

Accepted : 04.05.2017
Members of the Research Forum

Associated Authors:

'Department of Horticulture,

Vasantrao Naik Marathwada Krishi

Vidyapeeth, PARBHANI (M.S.) INDIA

Author for correspondence : S.S.YADLOD

Department of Horticulture, Vasantrao

Naik Marathwada Krishi Vidyapeeth,

PARBHANI (M.S.) INDIA

Email : shivayadlod@gmail.com
THEASIAN JOURNALOF HORTICULTURE

Volume 12 | Issue $1 \mid$ June, 2017 | 35-40

Visit us -www.researchjournal.co.in

RESEARCH PAPER

DOI : $10.15740 / \mathrm{HAS} / \mathrm{TAJH} / 12.1 / 35-40$

\title{
Effect of leaf density and bunches per vine on quality parameters of wine grape (Vitis vinifera L.) cv. SHIRAZ
}

\section{B.D. WAGHMARE ${ }^{1}$, S.S. YADLOD AND T.B. TAMBE ${ }^{1}$}

ABSTRACT : The present investigation was carried out at the vineyard of Kolpa village, Tal. Latur, dist. Latur during the year 2009-2010. The experiment was laid out in Factorial Randomized Block Design with two replications. The treatments consisted of four leaf densities i.e. (12, 14, 16 and 18) leaves per shoot with four number of bunches i.e. (25, 30, 35 and 40) per vine maintained after October pruning. The observations on leaf length, leaf width, leaf area, weight of 100 berries TSS, acidity, reducing sugar, non-reducing sugar and juice per cent were recorded. The maximum leaf length $(6.8 \mathrm{~cm})$ was observed in leaf density of 18 leaves per shoot however, minimum $(6.4 \mathrm{~cm})$ was recorded in leaf density of 14 leaves per shoot.The treatment combination of 18 leaves per shoot and the vines on which 35 bunches were maintained, recorded the highest leaf area index (3.00), however, minimum (1.64) was observed in treatment combination of 14 leaves per shoot and 25 bunches per vine. Significantly optimum TSS $\left(25.00^{\circ}\right.$ Brix $)$, acidity $(1.03, \%)$, reducing sugar $(18.51 \%)$, non-reducing sugar $(0.89 \%), \mathrm{pH}$ of juice $(3.2 \%)$ and juice per cent $(77.62 \%)$ was recorded in treatment combination of 18 leaves per shoot and 35 bunches per vines were maintained.

KEY WORDS : Shoot, Leaf length, Leaf area index, TSS, Acidity, Juice per cent

HOW TO CITE THIS ARTICLE : Waghmare, B.D., Yadlod, S.S. and Tambe, T.B. (2017). Effect of leaf density and bunches per vine on quality parameters of wine grape (Vitis vinifera L.) cv. SHIRAZ. Asian J. Hort., 12(1) : 35-40, DOI : 10.15740/HAS/TAJH/12.1/35-40. 